\title{
Hematological Side Effects of Valproate Used for the Treatment of Epilepsy
}

Epilepsi Tedavisinde Kullanılan Valproatın Hematolojik Yan Etkileri

\author{
(D) Pınar YILMAZBAŞ1 ${ }^{1}$, (D) Nesrin ŞENBIL 2
}

\author{
1 University of Health Sciences Turkey, Prof. Dr. Cemil Taşçıoğlu City Hospital, Clinic of Child Health and Pediatric Diseases, Istanbul, Turkey \\ ${ }^{2}$ Kırıkkale University Faculty of Medicine, Department of Pediatric Neurology, Kırıkkale, Turkey
}

\begin{abstract}
Aim: Valproate is a commonly used antiepileptic drug with hematologic and non-hematologic side effects at therapeutic doses. The aim of this study was to investigate the relationship between the known hematological side effects of valproate and duration, dose and serum levels of this drug.

Materials and Methods: The study population consisted of patients with epilepsy followed by pediatric neurology outpatient clinic, who had been using valproate for at least 3 months. Duration of treatment, valproate doses, hemogram and serum valproate levels of patients were recorded from their files. Patients with other systemic and/or hematological diseases and those who were taking drugs other than valproate were not included in the study. Results: Serum valproate levels and complete blood count results were obtained in 80 of 112 patients who met the criteria. Thirty of them (37.5\%) were female. The mean age was $8.2 \pm 4.8$ years (1-16 years) and the mean duration of treatment was $19.93 \pm 16.4$ months ( 3 months-10 years). Valproate use dose ranged from 20 to $60 \mathrm{mg} / \mathrm{kg}$ day. At least one hematologic side effect was detected in 34 (42\%) patients. These side effects were macrocytosis (18.7\%), thrombocytopenia (17.5\%), leukopenia (12.5\%) and anemia (7.5\%). There was no correlation between thrombocytopenia and valproate using time, but a significant correlation was found between dose and serum levels. There was a relationship between macrocytosis and serum valproate level only. No correlation was found between leukopenia and anemia and duration of treatment, dose and serum levels.

Conclusion: Hematological side effects of valproate used in the treatment of epilepsy are not uncommon, and these side effects are unpredictable. Therefore, it was concluded that complete blood counts should be sufficient in the follow-up of the patients and families should be informed about the side effects.
\end{abstract}

Keywords: Valproate, epilepsy, thrombocytopenia, anemia

\section{Öz}

Amaç: Valproat yaygın olarak kullanılan, tedavi dozlarında hematolojik ve hematolojik olmayan yan etkilere sahip antiepileptik bir ilaçtır. Bu çalışmada; tedavi dozunda kullanılan valproatın bilinen hematolojik yan etkilerinin (trombositopeni, lökopeni, anemi, makrositoz) ilaç kullanım süresi, dozu ve serum seviyesi ile ilişkisinin araştırılması amaçlanmıştır.

Gereç ve Yöntem: Çocuk nöroloji polikliniği tarafından epilepsi tanısı ile takip edilen ve en az 3 aydır valproat kullanmakta olan hastalar çalışma evrenini oluşturmuştur. Hastaların tedavi alma süreleri, kullandıkları valproat dozları, tam kan sayımı ve serum valproat düzeyleri dosyalarından kaydedilmiştir. Valproat dışında ilaç kullanan, başka bir sistemik ve/veya hematolojik hastalığı olan hastalar çalışmaya dahil edilmemiştir.

Bulgular: Çalışma kriterlerini karşılayan 112 hastadan 80'inin serum valproat düzeyi ve hemogram sonuçlarına ulaşılabildi. Hastaların 30'u (\%37,5)

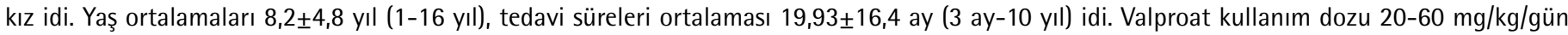
arasında değişmekte idi. Hastaların 34'ünde (\%42) en az bir hematolojik yan etki geliştiği saptandı. Bu yan etkiler makrositoz (\%18,7), trombositopeni $(\% 17,5)$, Iökopeni $(\% 12,5)$ ve anemi $(\% 7,5)$ idi. Trombositopeni ile valproat kullanım süresi arasında ilişki yok iken, ilaç kullanım dozu ve serum seviyesi ile anlamlı ilişki saptandı. Makrositoz ile sadece serum valproat seviyesi arasında ilişki saptandı. Lökopeni ve anemi ile valproat kullanım süresi, dozu ve serum seviyesi arasında ilişki saptanmadı.

Sonuç: Epilepsi tedavisinde kullanılan valproatın hematolojik yan etkilerinin nadir olmadığı, bu yan etkilerin önceden tahmin edilemeyeceği görülmektedir. Bu nedenle hastaların takibinde tam kan sayımının değerlendirilmesinin yeterli olacağı ve yan etkiler açısından ailelerin bilgilendirilmesi gerektiği sonucuna varılmıştır.

Anahtar Kelimeler: Valproat, epilepsi, trombositopeni, anemi

Address for Correspondence: Pınar YILMAZBAŞ MD, University of Health Sciences Turkey, Prof. Dr. Cemil Taşçığlu City Hospital, Clinic of Child Health and Pediatric Diseases, İstanbul, Turkey

E-mail: drpinary@yahoo.com ORCID ID: orcid.org/0000-0002-1283-1712

Received: 28.09.2020 Accepted: 15.12 .2020

Presented in: Our study was presented as an oral presentation at the $2^{\text {nd }}$ International Eurasian Congress of Social Pediatrics on date June 292019.

${ }^{\circ}$ Copyright 2021 by the Tekirdağ Namık Kemal University Faculty of Medicine / Namık Kemal Medical Journal published by Galenos Publishing House. 


\section{INTRODUCTION}

Valproate is an antiepileptic drug that is frequently used and effective in many seizure types'. Hematological and non-hematological side effects are observed in the treatment doses of valproate ${ }^{2}$. Hematological side effects include thrombocytopenia, leukopenia, anemia, bone marrow suppression, macrocytosis, prolonged bleeding time, platelet dysfunction, hypofibrinogenenia, factor XIII deficiency, myelodysplastic syndrome and increased hemoglobin $(\mathrm{Hb}) \mathrm{F}$ levels $\mathrm{s}^{3,4}$. Thrombocytopenia is the most common hematological side effect, usually dose dependent and transient. There is a correlation between high valproate plasma levels and thrombocytopenia. Thrombocytopenia begins to resolve within a few days with dose reduction ${ }^{5}$. In different studies, the incidence of thrombocytopenia due to valproate has been reported to be between $5 \%$ and $40 \%{ }^{5-}$ ${ }^{8}$. Macrocytosis is a side effect that can be seen in those receiving valproate therapy and is thought to be not dose dependent. Recovery of macrocytosis may take months after drug discontinuation ${ }^{9,10}$. In addition, valproate can cause bone marrow depression and myelodysplasia, affecting a single cell or whole cell series. The suppressive effect of valproate on the bone marrow regresses with the withdrawal of the drug, but supportive treatment may be required during the recovery period $^{11,12}$. Transient leukopenia can be seen during valproate therapy and has been shown to develop at a rate of $15-26 \%$ in studies ${ }^{10,13}$.

In this study, we aimed to investigate the relationship between the dose, serum level and duration of use of valproate and hematological side effects.

\section{MATERIALS AND METHODS}

Our study is a retrospective study. Patients who were diagnosed with epilepsy by the Pediatric Neurology Outpatient Clinic of Dr. Sami Ulus Child Health and Diseases Training and Research Hospital and who had been using valproate for at least 3 months constituted the study population.

Valproate usage doses, duration of treatment, $\mathrm{Hb}$ level, white blood cell count, platelet count, mean corpuscular volume (MCV) and serum valproate levels were recorded from the patients' files. Patients who used drugs other than valproate and had any other systemic and/or hematological diseases were not included in the study. The lower bound for platelet count was taken as $150,000 / \mathrm{mm}^{3}$, normal $\mathrm{Hb}$ values were accepted as $10.5-15 \mathrm{~g} / \mathrm{dL}$, white blood cell counts between 5,100 and 15,000 cells/uL and MCV counts between 76 and 90.1 micro $\mathrm{mm}^{3}$ values were considered as normal.

The follow-up of the hematological values (thrombocytopenia, anemia, macrocytosis, leukopenia) at the pathological margin and the times to return to normal were recorded from the patients' files. Our study was carried out according to the Declaration of Helsinki protocol. This study is the article of pediatrics speciality thesis, and it was made with the necessary permission taken from the Education Planning Board in November 2003 (10.021.2003). The relationship between the duration of valproate use, the dose of valproate and serum valproate levels of the patients and thrombocytopenia, anemia, leukopenia and macrocytosis were investigated.

\section{Statistical Analysis}

IBM SPSS Statistics 12 for statistical analysis (SPSS IBM, Turkey) program was used for evaluating the data obtained in the study. The Mann-Whitney U test was used to investigate the relationship between valproate duration, dose, serum level and anemia, leukopenia, thrombocytopenia and macrocytosis, and $p<0.05$ values were considered as statistically significant. Non-parametric tests were used for age and gender.

\section{RESULTS}

Of 112 patients meeting the study criteria, 80 patients who used only valproate as treatment and whose serum valproate level and hemogram results could be obtained were included in the study.

Thirty (37.5\%) of the patients were girls. The mean age was $8.2 \pm 4.8$ years ( $1-16$ years), the mean duration of treatment was $19.93 \pm 16.4$ months ( 3 months-10 years). Valproate usage dose varied between 20 and $60 \mathrm{mg} / \mathrm{kg} /$ day. Serum valproate levels of patients varied between 33 and $194 \mu / \mathrm{mL}$. Normal valproate serum levels were between 50 and $100 \mu / \mathrm{mL}, 6$ patients' serum valproate levels were under normal. Five patients' serum valproate levels were above normal, two of which were very high as 187 and $194 \mu / \mathrm{mL}$.

At least one hematological side effect was found in 34 $(42 \%)$ of the patients. These side effects were macrocytosis (18.7\%), thrombocytopenia (17.5\%), leukopenia (12.5\%) and anemia (7.5\%). Thrombocytopenia was detected in $14(17.5 \%)$ of the patients. While there was no relationship between thrombocytopenia and the duration of valproate use, a significant relationship was found with the usage dose, serum valproate level and thrombocytopenia (Table 1).

Fifteen (18.7\%) of the patients had macrocytosis and a relationship was found between macrocytosis and only serum valproate level (Table 2).

Leukopenia (12\%) was found in 10 patients and anemia (7.5\%) in 6 patients. No relationship was found between leukopenia and anemia and the duration, dose, and serum level of valproate. 


\section{DISCUSSION}

In this study, it was found that at least one hematological side effect developed in $42 \%$ of 80 patients who used valproate as a single antiepileptic drug, and hematological side effects related to valproate were not uncommon. On the other hand, it was observed that these side effects did not cause serious clinical problems. Consistent with other studies, the most common hematological side effect was macrocytosis ${ }^{10,14}$. A significant relationship was found between macrocytosis and serum valproate level, but the dose was not decreased due to macrocytosis. Thrombocytopenia, the second most common side effect, was detected at a rate of $17.5 \%$, and the lowest platelet count was measured as $33,000 / \mathrm{mm}^{3}$. None of the patients with thrombocytopenia developed bleeding diathesis and no platelet suspension was required. The dose of valproate was found to be very high in 2 of the patients (194 and $187 \mu / \mathrm{mL}$ ) and the treatment of these patients was continued with another drug apart from valproate. Twenty percent reduction was made in the treatment doses of the other 12 patients.

It was observed that the platelet counts returned to normal 1 week later in 7 patients, 2 weeks later in 5 patients. Since there was no seizure recurrence in patients with reduced valproate doses, their treatment was continued with reduced doses. Since there is no relationship between thrombocytopenia and the duration of treatment, it seems that patients can develop at any time during treatment and this cannot be predicted. Consistent with other studies, a significant relationship was found between valproate dose and serum level and thrombocytopenia ${ }^{8,10,15}$.

In patients with leukopenia, this side effect was observed to be independent of the duration of treatment, dose and serum level. It has been shown in previous studies that leukopenia is transient ${ }^{15,16}$. In our patients, leukopenia was not found to be life threatening, and the drug dose of the patients was not changed. The patients were followed up until the white blood cell count increased and the leukopenia was found to be transient.

Anemia developing due to valproate, occurs due to the toxic effect of valproate on DNA metabolism and cannot be predicted as stated in previous studies ${ }^{13,17,18}$. In our study, no relationship was found between anemia and the duration, dose and serum level of valproate. However, a patient who developed deep anemia was hospitalized for supportive treatment and her treatment was changed with another antiepileptic drug.

There is no consensus on the path to follow when hematological side effects develop during the use of valproate. General approach is to make small reductions (10-25\%) in treatment doses when thrombocytopenia develops, to continue at the same dose if the seizure is under control, and if there is no seizure control, to increase the dose gradually ${ }^{10}$. In patients with severe anemia, close follow-up of the patient, and if there is bone marrow suppression, continuing treatment with another drug is recommended. Dose reduction was sufficient when thrombocytopenia developed in our patients. In one patient who developed deep bone marrow suppression, treatment was continued with another antiepileptic.

There are different opinions about how often the patients should be tested during valproate treatment ${ }^{10,19,20}$. Since the hematological side effects cannot be predicted during valproate treatment, we think that it is important to follow up the patients and to inform families about the side effects of valproate, especially considering that there may be patients with mental motor retardation. It is thought that contacting the doctor may prevent the development of life-threatening complications when these side effects develop.

\section{Study Limitations}

Our study was a retrospective study and we could not investigate all hematological side effects like platelet

Table 1. Relationship between platelet count and valproate dose, duration, serum level

\begin{tabular}{|l|l|l|l|l|}
\hline & $\begin{array}{l}\text { Number of } \\
\text { patients }\end{array}$ & $\begin{array}{l}\text { Average duration of } \\
\text { valproate usage }(\mathbf{m o n t h s})\end{array}$ & $\begin{array}{l}\text { Valroate dose } \\
(\mathbf{m g} / \mathbf{k g} / \mathbf{d a y})\end{array}$ & $\begin{array}{l}\text { Valproate serum } \\
\text { level }(\boldsymbol{\mu} / \mathbf{m L})\end{array}$ \\
\hline Platelet count $<150,000 / \mathrm{mm}^{3}$ & 14 & 20.6 & 29.6 & 99.3 \\
\hline Platelet count $>150,000 / \mathrm{mm}^{3}$ & 66 & 19.8 & 22.5 & 65.9 \\
\hline$p$ & - & 0.176 & $<0.001$ & $<0.001$ \\
\hline
\end{tabular}

Table 2. Relationship between macrocytosis and valproate dose, duration, serum level

\begin{tabular}{|l|l|l|l|l|}
\hline & $\begin{array}{l}\text { Number of } \\
\text { patients }\end{array}$ & $\begin{array}{l}\text { Average duration of } \\
\text { valproate usage }(\mathbf{m o n t h s})\end{array}$ & $\begin{array}{l}\text { Valproate dose } \\
(\mathbf{m g} / \mathbf{k g} / \text { day })\end{array}$ & $\begin{array}{l}\text { Valproate serum } \\
\text { level }(\boldsymbol{\mu} / \mathbf{m L})\end{array}$ \\
\hline $\mathrm{MCV}<90$ micro $\mathrm{mm}^{3}$ & 65 & 19.7 & 23.8 & 67 \\
\hline $\mathrm{MCV}>90$ micro $\mathrm{mm}^{3}$ & 15 & 21 & 23.7 & 92.4 \\
\hline $\mathrm{p}$ & - & 0.532 & 0.587 & $<0.001$ \\
\hline $\mathrm{MCV}:$ Mean corpuscular volume & \multicolumn{5}{|l}{} \\
\hline
\end{tabular}


dysfunction, hypofibrinogenenia, and factor XIII deficiency, which was a limitation.

\section{CONCLUSION}

It is seen that the hematological side effects of valproate used in the treatment of epilepsy are not uncommon and these side effects cannot be predicted. Therefore, evaluation of complete blood count would be sufficient in the follow-up of these patients, and families should be informed about the side effects.

\section{Ethics}

Ethics Committee Approval: The study was the Pediatrics Speciality Thesis of Pınar Yılmazbaş and was approved by Dr. Sami Ulus Obstetrics and Gynecology, Child Health and Diseases Training and Research Hospital (73799008-799).

Informed Consent: Consent form was filled out by all participants.

Peer-review: Externally peer-reviewed.

\section{Authorship Contributions}

Surgical and Medical Practices: N.Ş., P.Y., Concept: P.Y., N.Ş., Design: P.Y., N.S.., Data Collection or Processing: P.Y., Analysis or Interpretation: P.Y., Literature Search: N.Ş., P.Y., Writing: P.Y.

Conflict of Interest: No conflict of interest was declared by the authors.

Financial Disclosure: The authors declared that this study received no financial support.

\section{References}

1. Aicardi J. Epilepsi and other seizure disorders in disease of the nervous system in childhood. Aicardi J (ed), 2nd edition. London, Mac Keith Press, 1998; p. 575-623.

2. Baudou E, Benevent J, Montastruc JL, Touati G, Hachon LeCamus C. Adverse Effects of Treatment with Valproic Acid during the Neonatal Period. Neuropediatrics. 2019;50:31-40.
3. Shorvon S. Antiepileptic Drugs In: Handbook of epilepsi treatment. Shorvon $S$ (ed), Oxford, Blackwell Science, 2000; p. 146-51.

4. Amitai M, Sachs E, Zivony A, Remez R, Ben Baruch R, Amit BH, et al. Effects of long-term valproic acid treatment on hematological and biochemical parameters in adolescent psychiatric inpatients: a retrospective naturalistic study. Int Clin Psychopharmacol. 2015;30:241-8.

5. Buoli M, Serati M, Botturi A, Altamura AC. The Risk of Thrombocytopenia During Valproic Acid Therapy: A Critical Summary of Available Clinical Data. Drugs R D. 2018;18:1-5.

6. Kumar R, Vidaurre J, Gedela S. Valproic Acid-Induced Coagulopathy. Pediatr Neurol. 2019;98:25-30.

7. Ohtsuka $Y$, Amano R, Mizukawa M, Oka E, Ohtahara S. Treatment of intractable childhood epilepsy with high-dose valproate. Epilepsia. 1992;33:158-64.

8. Kurahashi $H$, Takami A, Murotani K, Numoto S, Okumura A. Decreased platelet count in children with epilepsy treated with valproate and its relationship to the immature platelet fraction. Int J Hematol. 2018;107:10511.

9. Davis RB, Sunder TR, Barakat HA, May R. Valproate Alters the Membrane Phospholipids of Erythrocytes. Epilepsia. 1991;32;11-2.

10. May RB, Sunder TR. Hematologic manifestations of long-term valproate therapy. Epilepsia. 1993;34:1098-101.

11. Acharya S, Bussel JB. Hematologic toxicity of sodium valproate. J Pediatr Hematol Oncol. 2000;22:62-5.

12. Ganick DJ, Sunder T, Finley JL. Severe hematologic toxicity of valproic acid. A report of four patients. Am J Pediatr Hematol Oncol. 1990;12:80-5.

13. Barr RD, Copeland SA, Stockwell ML, Morris N, Kelton JC. Valproic acid and immune thrombocytopenia. Arch Dis Child. 1982;57:681-4.

14. Ozkara $\mathrm{C}$, Dreifuss $\mathrm{FE}$, Apperson Hansen $\mathrm{C}$. Changes in red blood cells with valproate therapy. Acta Neurol Scand. 1993;88:210-2.

15. Zeller JA, Schlesinger $S$, Runge $U$, Kessler $C$. Influence of valproate monotherapy on platelet activation and hematologic values. Epilepsia. 1999;40:186-9.

16. Symon DN, Russell G. Sodium valproate and neutropenia. Arch Dis Child. 1983;58:235.

17. MacDougall LG. Pure red cell aplasia associated with sodium valproate therapy. JAMA. 1982;247:53-4.

18. Ganick DJ, Sunder T, Finley JL. Severe hematologic toxicity of valproic acid. A report of four patients. Am J Pediatr Hematol Oncol. 1990;12:80-5.

19. Eshiet UI, Ubaka CM, Ukwe CV. Infrequent Monitoring of the Effects of Valproate and Carbamazepine Therapy in Patients With Epilepsy in Nigeria. J Cent Nerv Syst Dis. 2020;12:1179573520925934.

20. Li C, Su L, Lao M, Zhu S, Ding M. Anemia secondary to the use of sodium valproate for preventing postoperative seizures in a 79-year-old man: A case report. Medicine (Baltimore). 2018;97:13626. 